\title{
О.В. Ромашко-Майструк
}

Національний університет водного господарства та природокористування, Рівне, Україна

\section{ДОСЛІДЖЕННЯ РІВНЕВОГО УТВОРЕННЯ ТА РОЗКРИТТЯ НОРМАЛЬНИХ ТРІЩИН В ЗАЛІЗОБЕТОННИХ ЕЛЕМЕНТАХ}

Дана стаття присвячена виявленню основних закономірностей багаторівневого утворення нормальних тріщин в залізобетонних елементах і конструкціях. Виконано критичний аналіз останніх публікацій, пов'язаних з вказаною тематикою. Дослідами встановлено основні закономірності рівневого утворення та розкриття нормальних тріщин в згинальних елементах. Статистично підтверджено ефективність тих методик розрахунку, в яких крок утворення тріщин безпосередньо пов'язаний з параметрами зчеплення арматури з бетоном.

Ключові слова: залізобетон, елементи, зчеплення, арматура, тріщини, рівні утворення, крок, иирина.

\section{Постановка проблеми}

Загалом відомо, що процеси утворення та розвитку тріщин, зокрема і нормальних, суттєвим чином впливають на експлуатаційні властивості залізобетонних елементів і конструкцій. Тому цілком очевидно, що питання їх тріщиностійкості завжди залишатимуться одними із визначальних в теорії деформування залізобетону. А із запровадженням в сучасну практику проектування деформаційних методів розрахунку залізобетонних елементів i конструкцій, вони набувають ще більшої вагомості та актуальності. Адже з використанням деформаційних моделей появляється можливість більш точного відтворення реального напружено-деформованого стану залізобетонних елементів i конструкцій в процесі їх деформування.

Водночас результати експериментальних досліджень вказують на те, що утворення і розвиток тріщин в залізобетонних елементах є багаторівневим та призводить до поступового порушення взаємодії арматури з розтягнутим бетоном. За таких обставин, загальну методику розрахунку утворення та розкриття нормальних тріщин доцільно було б розбудовувати на основі безпосереднього залучення визначальних закономірностей зчеплення арматури 3 бетоном. У протилежному випадку розрахунок ширини розкриття нормальних тріщин за гіпотезою Томаса [1] буде i далі залишатися переважно декларативним. Обумовлено це тим, що виконати зазначений розрахунок за формулою:

$$
w_{k}=2 \int_{o}^{0,5 s_{r}} \varepsilon_{\tau}(z) d z,
$$

3 позицій послідовного накопичення взаємних зміщень бетону і арматури, вкрай складно. Пряме інтегрування виразу (1) у більшості випадків здійснити практично неможливо, оскільки дійсна залежність взаємних зміщень арматури і бетону $\varepsilon_{\tau}(z)=\varepsilon_{s}(z)-\varepsilon_{c t}(z) \epsilon$ дуже складною та не може бути описана єдиною функцією. Однак розрахунок ширини розкриття нормальних тріщин можна суттєво спростити, якщо крок тріщин та ширину їх розкриття пов'язати безпосередньо 3 зусиллями зчеплення арматури з бетоном та врахувати, що процес утворення тріщин є багаторівневим. Тому можливість та доцільність такого підходу до розрахунку основних параметрів тріщиностійкості залізобетонних елементів i конструкцій потребує спеціальних досліджень.

\section{Аналіз останніх досліджень та публікацій}

Дослідженню тріщиностійкості залізобетонних елементів і конструкцій присвячено дуже багато робіт вітчизняних, а ще більше зарубіжних вчених. Однак лише окремі із них були спрямовані на виявлення загальних закономірностей реального рівневого утворення та розвитку нормальних тріщин 3 урахуванням зчеплення арматури 3 бетоном. Їх можна умовно розділити за 4-ма наступними напрямами.

В роботах першого напряму вплив зчеплення арматури 3 бетоном на послідовність утворення i розвитку нормальних тріщин моделюють шляхом безпосереднього інтегрування діаграм взаємного зміщення бетону і арматури [2-4]. Однак реалізувати цей спосіб в практичних розрахунках вкрай складно, оскільки форма зазначених діаграм в процесі деформування залізобетонних елементів постійно 
змінюються [5-7], що робить їх безпосереднє інтегрування практично неможливим.

Тому роботи другого напряму [8-11] в основному скеровані на числові способи розрахунку багаторівневого утворення і розкриття нормальних тріщин. Їх реалізація можлива лише методами скінчених елементів за допомогою спеціальних програмних комплексів. Доволі часто це веде до того, що інженерна осяжність та фізична сутність процесів зчеплення арматури 3 бетоном та тріщиноутворення в залізобетонному елементі частково втрачається або нівелюється.

В дослідженнях 3-го напряму використовується спеціальний «двоконсольний» елемент [12, 13]. Методика, побудована 3 його допомогою, загалом дозволяє моделювати рівневе утворення нормальних тріщин. Але на сьогодні їі реалізація в практичних розрахунках залишається іще доволі складною із-за значних труднощів, пов'язаних 3 «виділенням» або формуванням самого «двоконсольного» елемента, а тому є можливою лише за допомогою спеціальних комп'ютерних програм.

В роботах 4-го напряму методики розрахунку рівневого утворення нормальних тріщин будуються за допомогою загальної функції середніх напружень зчеплення арматури з бетоном [14-16]. Вони $€$ доволі простими для реалізації в практичних розрахунках. Однак залишається відкритим питання щодо обгрунтованості форми зв'язку (лінійного чи нелінійного) між середніми значеннями напружень зчеплення арматури 3 бетоном та середніми значеннями нормальних напружень в самій арматурі на всіх етапах деформування залізобетонного елемента.

\section{Мета та завдання досліджень}

Дані дослідження були спрямовані на експериментально-теоретичне обгрунтування форми зв'язку (лінійного чи нелінійного) між середніми значеннями напружень зчеплення арматури 3 бетоном та середніми значеннями нормальних напружень в самій арматурі.

Для досягнення поставленої мети ставились наступні завдання:

- дослідити закономірності багаторівневого утворення та розкриття нормальних тріщин в згинальних елементах шляхом випробування залізобетонних балок;

- розрахувати за різними методиками ширину розкриття нормальних тріщин при їх рівневому утворенні;

- виконати відповідні статистичні порівняння отриманих результатів розрахунку 3 дослідними даними.

\section{Виклад основного матеріалу}

3 метою розв'язання вищевказаних завдань, було вирішено виготовити та випробувати три залізобетонні балки довжиною 2000 мм з розмірами поперечного перерізу 200x100 мм. Дійсні значення геометричних характеристик цих балок наведено в табл. 1.

Таблиця 1

Геометричні характеристики дослідних балок

\begin{tabular}{|c|c|c|c|c|c|c|}
\hline $\begin{array}{c}\text { Шифри } \\
\text { балок }\end{array}$ & $\begin{array}{c}L, \\
\text { Мм }\end{array}$ & $\begin{array}{c}b, \\
\text { MM }\end{array}$ & $\begin{array}{c}h, \\
\text { мм }\end{array}$ & $\begin{array}{l}a_{1}, \\
\mathrm{MM}\end{array}$ & $\begin{array}{l}a_{2}, \\
\mathrm{MM}\end{array}$ & $\begin{array}{l}A_{s}, \\
\mathrm{~cm}^{2}\end{array}$ \\
\hline Б-1 & \multirow{3}{*}{2000} & 101 & 199 & 14 & 13 & \multirow{3}{*}{1,57} \\
\hline Б-2 & & 104 & 200 & 12 & 14 & \\
\hline Б-3 & & 102 & 198 & 12 & 12 & \\
\hline
\end{tabular}

В нижній розтягнутій зоні балки армувалися двома поздовжніми стержнями діаметром $10 \mathrm{mм}$ класу А500С. На приопорних ділянках, поза зоною чистого згину, було встановлено поперечні стержні діаметром 4 мм 3 арматури класу Bp-I у вигляді гнутих замкнутих хомутів. Вони розміщувалися 3 кроком 100 мм. Верхні конструктивні стержні в зазначеній зоні також були діаметром 4 мм 3 арматури класу Вр-I (рис. 1).
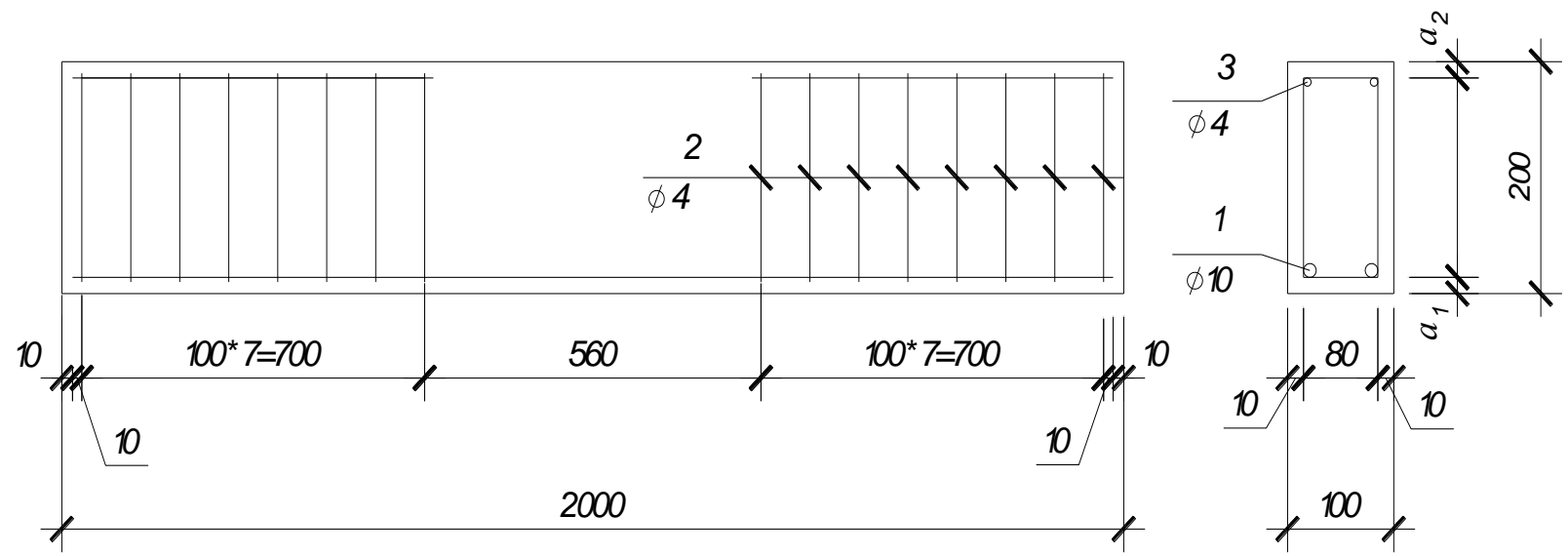

Рис. 1. Конструкція та схема армування залізобетонних балок: $a_{l}$ та $a_{2}$ - захисний шар бетону нижньої робочої та верхньої конструктивної арматури відповідно 
Всі балки були виготовлені 3 важкого бетону класу C20/25. Приготування бетонної суміші та формування дослідних зразків проводилося в лабораторних умовах. Їх бетонування виконувалося у спеціальних металевих формах в горизонтальному положенні. Бетонна суміш ущільнювалася на спеціальному вібромайданчику. Твердіння бетону проходило за нормальних умов навколишнього середовища в науковій лабораторії кафедри промислового, цивільного будівництва і інженерних споруд. Підготовка всіх дослідних зразків до випробувань розпочиналася при досягненні ними 28 денного віку.

Випробування балок проводили в спеціальній рамній установці за схемою однопролітної шарнірно обпертої на опорах балки з прольотом 1800 мм. Для влаштування зони чистого згину їх завантажували двома зосередженими силами в середній третині розрахункового прольоту через розподільну металеву траверсу. Навантаження створювалося за допомогою 15 -ти тонного гідравлічного домкрату і ручної насосної станції та контролювалося за відтарованим кільцевим динамометром.

Прогини балки та іiі осідання на опорах контролювали за допомогою прогиномірів 6ПАО. Деформації стиснутого бетону вимірювали за допомогою індикаторів 1МИГ, що були встановлені 3 базою вимірювань 200 мм в середній частині балки. Деформації нижньої арматури контролювали за допомогою звичайних тензометрів Гугенбергера, встановлених посередині прольоту балки на кожному 3 розтягнутих стержнів. Виникнення та розвиток нормальних тріщин в балках фіксували візуально, а ширину ї розкриття досліджували за допомогою мікроскопа МПБ-3 з ціною поділки

\section{0,02 мм.}

Балки завантажувалися ступенями, рівними приблизно 1/10 від теоретичної несучої здатності $\left(M_{u}\right) .3$ метою фіксації утворення перших тріщин величину 4-х початкових ступенів навантаження була зменшено до $1 / 20$ від $M_{u}$. Задля фіксації моменту втрати несучої здатності балок такими ж приймали і 2-а заключні ступені їх завантаження.

Результати експериментальних досліджень підтвердили, що процес утворення нормальних тріщин у залізобетонних балках в дійсності $\epsilon$ багаторівневим (рис. 2).

Перші тріщини в балках утворювалися на $3 \ldots 4$ ступенях завантаження за згинаючих моментів $M_{w, 1} \approx(0,125 \ldots 0,17) M_{u}$. Їх крок був $80 \ldots 205$ мм, а ширина розкриття складала $0,02 \ldots 0,05$ мм.

Тріщини другого рівня виникали на $6 \ldots 7$ ступенях навантаження за згинаючих моментів $M_{w, 2} \approx(0,33 \ldots 0,5) M_{u}$. Крок між ними становив вже $60 \ldots 105$ мм, а ширина розкриття магістральних тріщин сягала 0,09...0,13 мм. Було помічено, що 3 утворенням тріщин другого рівня інтенсивність їх розкриття на певний час дещо пригальмовувалась».

Тріщини 3-го рівня почали з'являтися на $8 \ldots 12$ ступенях завантаження за згинаючих моментів $M_{w, 3} \approx(0,78 \ldots 0,95) M_{u}$, тобто незадовго або під час текучості арматури. Відстань між нормальними тріщинами зменшувалась до $30 \ldots 70$ мм, а ширина їх розкриття збільшувалась до $0,17 \ldots 0,22$ мм.
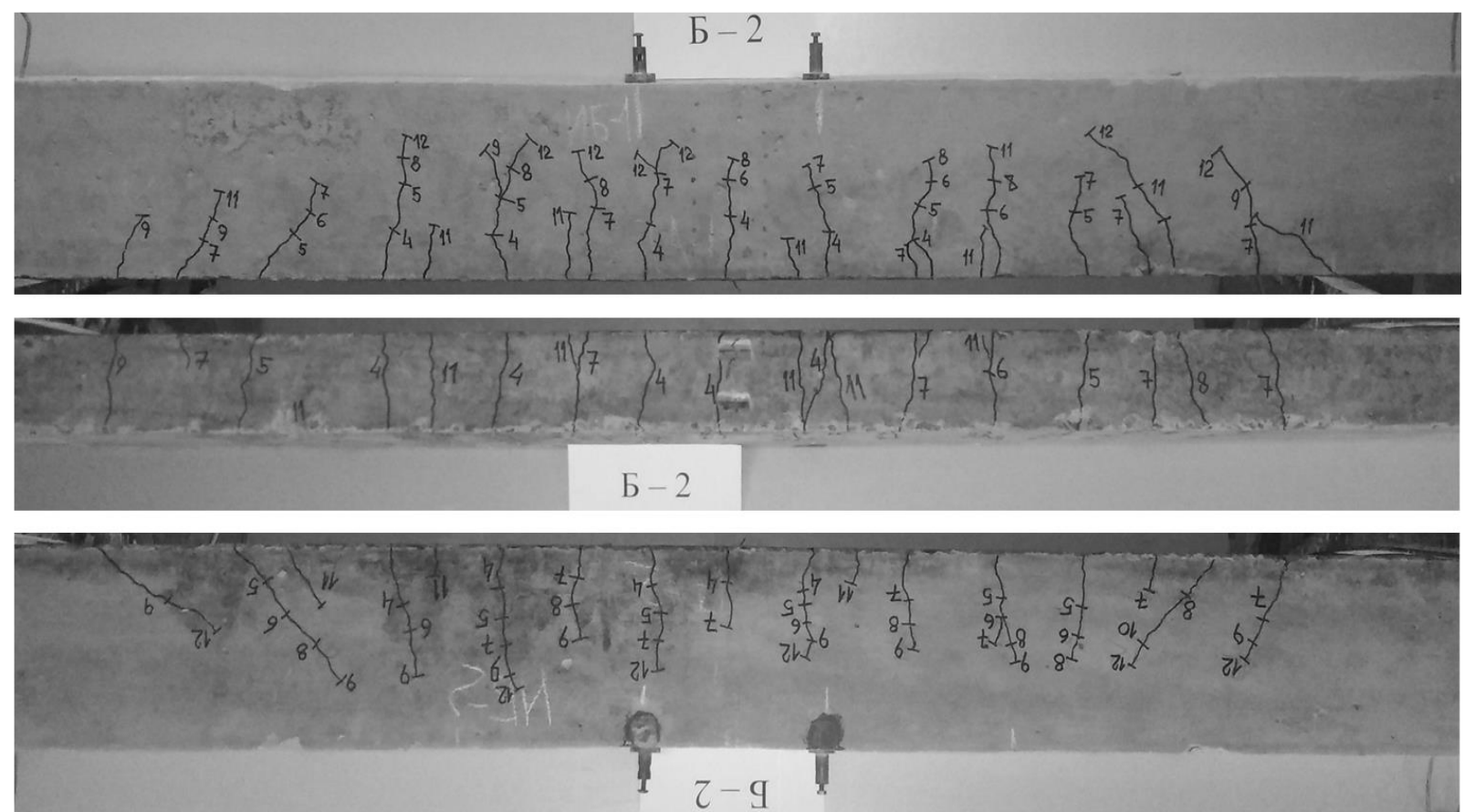

Рис. 2. Розгортка утворення та розвитку тріщин в балці Б-2 
Зважаючи на результати експериментальних досліджень, теоретичні значення ширини розкриття магістральних нормальних тріщин в балках розраховували за схемою дворівневого їх утворення [17] згідно залежності:

$$
w_{k}=s_{r 1}\left(\varepsilon_{s m}-\varepsilon_{c t m}\right)-s_{r 2}\left(\varepsilon_{s m}-\varepsilon_{s m, c r 2}-\varepsilon_{c t m}\right)
$$

де $s_{r 1}$ i $s_{r 1}$ - крок між суміжними тріщинами на 1му та 2-му рівнях їх утворення; $\varepsilon_{s m}-$ значення середніх деформацій розтягнутої арматури на ділянці між суміжними нормальними тріщинами;

$$
\begin{aligned}
& \text { - статичних } M=f\left(\varepsilon_{c}, \varepsilon_{c t}, \varepsilon_{s}\right), \quad N=f\left(\varepsilon_{c}, \varepsilon_{c t}, \varepsilon_{s}\right) ; \\
& \text { - геометричних } 1 / r=f\left(\varepsilon_{c}, \varepsilon_{c t}, \varepsilon_{s}\right) ; \\
& \text { - фізичних } \sigma_{c}=f\left(\varepsilon_{c}\right), \sigma_{c t}=f\left(\varepsilon_{c t}\right), \sigma_{s}=f\left(\varepsilon_{s}\right) .
\end{aligned}
$$

$\varepsilon_{c t m}$ - середні деформації розтягнутого бетону на тій же ділянці; $\varepsilon_{s m, c r 2}$ - середні деформації розтягнутої арматури на найбільш напруженій ділянці між суміжними тріщинами на момент появи тріщин другого рівня.

Всі вищевказані деформації визначали згідно деформаційно-силової моделі (ДСМ) [18] за розв'язком загальновідомої системи найпростіших співвідношень механіки деформованого твердого тіла:

Відстань між тріщинами певного рівня $s_{r i}$ визначали згідно рівноваги максимально можливих зусиль в розтягнутому бетоні $N_{c t, c r}=f\left(\varepsilon_{c t u}\right)$ та зусиль активного зчеплення арматури 3 бетоном $N_{b d, c r}$ на ділянці між зазначеними тріщинами [16] за виразом:

$$
s_{r i}=\frac{\varnothing_{s}}{4 \cdot \tau_{b m i} \cdot \rho_{l, t}},
$$

де $\varnothing_{s}$ - діаметр стержнів робочої арматури; $\tau_{b m i}-$ значення середніх напружень зчеплення арматури 3 бетоном на ділянці між суміжними тріщинами відповідного рівня; $\rho_{l, t}-$ коефіцієнт армування розтягнутої зони залізобетонного елемента $\left(\rho_{l, t}=A_{s} / A_{c t, c r}\right)$.

Середні напруження зчеплення арматури 3 бетоном приймалися за узагальненою нелінійною функцією автора [15]:

$$
\tau_{b m i}=\eta_{1} \cdot \eta_{2} \cdot f_{c t k} \cdot\left(\sigma_{s i} / f_{y k}\right)^{1-1 / \eta_{1}}
$$

та за лінійною функцією, наведеною в роботі [14]:

$$
\tau_{m, i}=f_{c t m} \cdot\left(\frac{\eta_{1} \cdot \eta_{2}-\alpha_{0}}{f_{y d}} \cdot \sigma_{s i}+\alpha_{0}\right)
$$

де $\eta_{1}$ - коефіцієнт, що враховує профіль арматури за індексом зчеплення, приймався згідно [19]; $\eta_{2}-$ коефіцієнт, що враховує діаметр арматури; $f_{c t k}$ та $f_{c t m}$ - характеристичне та середнє значення міцності бетону за осьового розтягу; $\sigma_{s i}-$ найбільші нормальних напружень в арматурі на

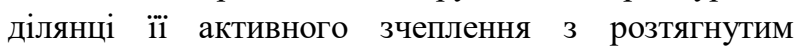
бетоном, за яких виникають тріщини певного рівня $\left(\sigma_{s i}=\sigma_{s, c r i}\right) ; \quad \sigma_{s, \max }-$ максимально можливі напруження в розтягнутій арматурі на ділянці іiі активного зчеплення 3 розтягнутим бетоном (не можуть перевищувати граничних значень $f_{y k} ; \alpha_{0}-$ коефіцієнт пропорційності між початковими напруженнями зчеплення арматури 3 бетоном та напруженнями в розтягнутому бетоні.

Крім того, розрахунки були виконані i за традиційними схемами «однорівневого» утворення нормальних тріщин згідно чинних норм [20, 21] та будівельних правил [22], а також за спрощеною методикою автора, в якій замість нелінійної функції (5) використано фіксовані осереднені значення середніх напружень зчеплення арматури з бетоном. Їх обчислювали за доволі простим виразом:

Графіки експериментальних та теоретичних значень ширини розкриття тріщин, розрахованих за вищевказаними методиками, приведені на рис. 3, а основні статистичні характеристики їхнього порівняння занесені до табл. 2.

Таким чином, вищеотримані результати проведених досліджень наглядно демонструють, що в реальному проектуванні залізобетонних елементів i конструкцій перевагу матимуть ті методики, які враховують багаторівневе утворення нормальних тріщин.

\section{Висновки}

Завдяки результатам проведених досліджень можна зробити низку висновків.

1. В реальному проектуванні згинальних

$$
\tau_{b m}=\eta_{1} \cdot \eta_{2} \cdot f_{c t k} / 2
$$


залізобетонних елементів та конструкцій при розрахунку їх тріщиностійкості достатньо обмежуватися лише 2-ма рівнями утворення нормальних тріщин.

2. Методики розрахунку тріщиностійкості, побудовані з залученням основних закономірностей зчеплення арматури 3 бетоном, дозволяють більш точно відтворювати реальний процес утворення та розкриття нормальних тріщин в залізобетонних елементах.

3. Процес рівневого утворення нормальних тріщин в залізобетонних елементах можна відносно просто контролювати за допомогою функції середніх напружень зчеплення арматури з бетоном.

4. Нелінійна функція середніх напружень зчеплення арматури з бетоном дозволяє більш точно визначати основні параметри утворення та розкриття нормальних тріщин порівняно $з$ лінійною.

5. В перспективі було б доцільно дослідити вплив попереднього напруження на процес «рівневого» утворення та розкриття нормальних тріщин. Цілком очевидно, що це потребує окремого дослідження.

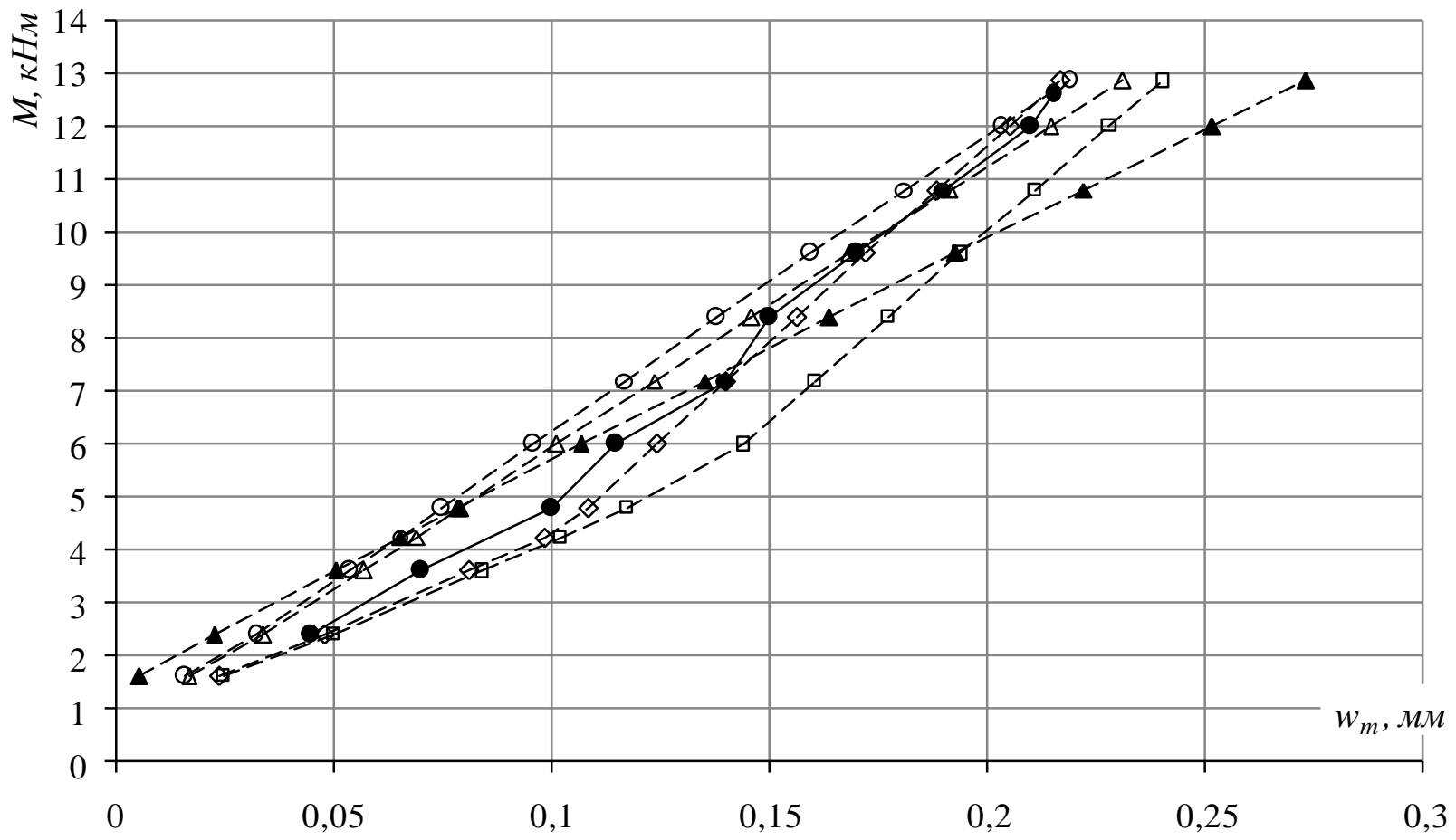

Рис. 3. Графіки ширини розкриття тріщин $\left(w_{m}\right)$ в балці Б -3 залежно від згинаючих моментів $(M)$ експериментальні; теоретичні згідно методики $\Delta$ - норм [20; 21], $\mathbf{\Delta - C П ~ [ 2 2 ] , ~ 口 - Д С М ~ з ~ л і н і и ̆ н и м и ~}$ $\tau_{b m}[14], \diamond$-загальної автора, о - спрощеної автора

Таблиця 2

Статистична оцінка методик розрахунку ширини розкриття нормальних тріщин в балках Б-1..Б-3

\begin{tabular}{|c|c|c|c|}
\hline \multirow{2}{*}{ Методика розрахунку } & \multicolumn{2}{|c|}{ Відхилення від дослідних даних } & \multirow{2}{*}{$\begin{array}{c}\text { Коефіцієнт } \\
\text { варіації } v_{w}, \%\end{array}$} \\
\hline & середньо арифметичне $\Delta_{w}, \%$ & середньо квадратичне $\sigma_{w}, \%$ & \\
\hline норм $[20 ; 21]$ & 7,26 & 10,74 & 11,58 \\
\hline $\mathrm{C \Pi}[22]$ & 3,0 & 23,14 & 23,87 \\
\hline ДСМ і лінійних $\tau_{b m}$ [14] & 16,04 & 5,17 & 4,46 \\
\hline загальна автора & 5,0 & 6,6 & 6,29 \\
\hline спрощена автора & 12,93 & 9,57 & 10,99 \\
\hline
\end{tabular}

\section{Література}

1. Thomas, F. G. (1936). Cracking in Reinforced Concrete. The Structural Engineer, 14(7), 298-320.

2. Alvarez, M. (1998). Einfluss des Verbundverhaltens auf das Verformungsvermögen von Stahlbeton: Abhandlung zur Erlangung des Titels Doktor der Technischen Wissenschaften.
Eidgenössischen Technischen Hochschule.

3. Fernández Ruiz, M., Hars, E., Muttoni, A. (2005). Bond mechanics in structural concrete (theoretical model and experimental results). Lausanne: Ecole Polytechnique F'ed'erale de Lausanne.

4. Рудный, И. А. Трещииностойкость растянутых и 
изгибаемых железобетонных элементов с участками нарушенного сиелления [Текст]: автореф. дис. ... канд. техн. наук: 05.23 .01 / И. А. Рудный; [СанктПетербургский государственный архитектурностроительный университет]. - Санкт-Петербург, 2015. $-22 c$.

5. Eligehausen, R., Popov, E. P. and Bertero, V. V. (1983). Local bond stress-slip relationships of deformed bars under generalized excitations: Report No. UCB/EERC-83/23. Berkeley: Earthquake Engineering Research Center of California University.

6. Shima, H., Chou, L.-L. and Okamura, H. (1987). Micro and macro models for bond in reinforced concrete. Journal of the Engineering Faculty of Tokyo University, XXXIX(2), 133194.

7. Harajli, M. H., Hout, M.A. and Jalkh, W. (1995). Local bond stress-slip behavior of reinforced bars embedded in plain and fiber concrete. ACI Materials Journal, 92(4), 343-353.

8. Карпенко Н. И. Общие модели механики железобетона [Текст] / Н. И. Карпенко. - Москва: Стройиздат, 1996. - 416 c.

9. Веселов, A. A. Нелинейная теория сиепления арматуры с бетоном и ее приложения [Текст]: автореф. дис. ... д-ра техн. наук: 05.23.01 / А. А. Веселов [СанктПетербургский государственный архитектурностроительный университет]. - Санкт-Петербург, 2000. $-44 c$.

10. Бенин, А. В. Математическое моделирование процесса разрушения сиепления арматуры с бетоном. Часть 1. Модели с учетом несплошности соединения [Текст] / A. В. Бенин, А. С. Семенов, С. Г. Семенов и др. // Инженерностроительный журнал. - 2013. - №5(40). - С. 86-99.

11. Shardakov, I. N., Bykov, A. A., Shestakov, A. P., Glot, I. O. (2016). Process of cracking in reinforced concrete beams (simulation and experiment). Frattura ed Integrità Strutturale, 38, 339-350.

12. Колчунов, В. И. Разработка двухконсольного элемента механики разрушения для расчета ширины раскрытия трещин железобетонных конструкиий [Текст] / В. И. Колчунов, И. А. Яковенко // Вестник гражданских инженеров СПбГАСУ. - 2009. - № 4(21). C. 160-163.

13. Яковенко I. А. Моделі деформування залізобетону на засадах механіки руйнування [Текст]: автореф. дис. ... дра техн. наук: 05.23.01 / I. А. Яковенко [Полтавський національний технічний університет]. - Полтава, 2018. $44 \mathrm{c}$.

14. Кочкарьов Д. В. Нелінійний опір залізобетонних елементів $i$ конструкиій силовим впливам [Текст]: автореф. дис. ... д-ра техн. наук: 05.23.01 / Д. В. Кочкарьов [Полтавський начіональний технічний університет]. - Полтава, 2018. - 43 с.

15. Romashko, O. and Romashko, V. (2018). Evaluation of bond between reinforcement and concrete. MATEC Web of Conf, 230, 02027.

16. Ромашко, В. М. Розрахунок тріщиностійкості залізобетонних елементів з урахуванням рівнів утворення нормальних тріщин [Текст] / В. М. Ромашко, О. В. Ромашко // Зб. наук. праиь УДУЗТ. - 2018. - Bun. 181. - C. 58-65.

17. Romashko, O. V. and Romashko, V. M. (2019). Model of multilevel formation of normal cracks in reinforced concrete elements and structures. IOP Conf. Ser.: Materials Science and Engineering, 708(1), 012069.

18. Romashko, V. and Romashko, O. (2017). The construction peculiarities of the deformation and power model of concrete and reinforced concrete resistance. MATEC Web of Conf, 116, 02028 .

19. Ромашко, В. М. Деформаиійно-силова модель опору бетону $i$ залізобетону [Текст]: монографія / В. М. Ромашко. - Рівне: О. Зень, 2016. - 424 c.

20. ДСТУ Б В.2.6-156: 2010. Конструкиії будинків $i$ споруд. Бетонні та залізобетонні конструкиії з важкого бетону. Правила проектування [Текст]. - Чинний від 01.06.11. - Київ: Мінрегіонбуд Украӥни, 2011. - 123 с.

21. EN 1992-1-1. (2004). Eurocode 2: Design of Concrete Structures. Part 1-1: General Rules and Rules for Buildings. Brussels: CEN.

22. СП 63.13330.2012. Бетонные $и$ железобетонные конструкиии. Основные положения. Актуализированная редакиия СНиП 52-01-2003 [Текст]. - Введен 01.01.2013. - Москва: Минрегион России, 2013. - 155 c.

\section{References}

1. Thomas, F. G. (1936). Cracking in Reinforced Concrete. The Structural Engineer, 14(7), 298-320.

2. Alvarez, M. (1998). Einfluss des Verbundverhaltens auf das Verformungsvermögen von Stahlbeton: Abhandlung zur Erlangung des Titels Doktor der Technischen Wissenschaften. Eidgenössischen Technischen Hochschule.

3. Fernández Ruiz, M., Hars, E., Muttoni, A. (2005). Bond mechanics in structural concrete (theoretical model and experimental results). Lausanne: Ecole Polytechnique F'ed'erale de Lausanne.

4. Rudny, I. A. (2015). Crack resistance of stretched and bent reinforced concrete elements with areas of broken adhesion: author. dis. ... cand. tech. sciences. Saint-Petersburg: State University of Architecture and Civil Engineering.

5. Eligehausen, R., Popov, E. P. and Bertero, V. V. (1983). Local bond stress-slip relationships of deformed bars under generalized excitations: Report No. UCB/EERC-83/23. Berkeley: Earthquake Engineering Research Center of California University.

6. Shima, H., Chou, L.-L. and Okamura, H. (1987). Micro and macro models for bond in reinforced concrete. Journal of the Engineering Faculty of Tokyo University, XXXIX(2), 133194.

7. Harajli, M. H., Hout, M.A. and Jalkh, W. (1995). Local bond stress-slip behavior of reinforced bars embedded in plain and fiber concrete. ACI Materials Journal, 92(4), 343-353.

8. Karpenko, N. I. (1996). General models of reinforced concrete mechanics. Moscow: Stroyizdat.

9. Veselov, A. A. (2000). Nonlinear theory of coupling of reinforcement with concrete and its applications: author. dis. ... doctor tech. sciences. Saint-Petersburg: State University of Architecture and Civil Engineering.

10. Benin, A. V., Semenov, A. S., Semenov, S. G., Melnikov, B. E. (2013). Mathematical modeling of the process of destruction of the bond between reinforcement and concrete. Part 1. Models taking into account the discontinuity of the connection. Engineering and construction journal, 5(40), 8699.

11. Shardakov, I. N., Bykov, A. A., Shestakov, A. P., Glot, I. O. (2016). Process of cracking in reinforced concrete beams 
(simulation and experiment). Frattura ed Integrità Strutturale, 38, 339-350.

12. Kolchunov, V. I., Yakovenko, I. A. (2009). Development of a two-console element of fracture mechanics for calculating the width of crack opening in reinforced concrete structures. Bulletin of civil engineers SPbGASU, 4(21), 160-163.

13. Yakovenko, I. A. (2018). Models of deformation of reinforced concrete on the basis of fracture mechanics: author. dis. ... doctor tech. Sciences. Poltava: National Technical University.

14. Kochkarev, D. V. (2018). Nonlinear resistance of reinforced concrete elements and structures to force influences: author. dis. ... doctor tech. sciences. Poltava: National Technical University.

15. Romashko, O. and Romashko, V. (2018). Evaluation of bond between reinforcement and concrete. MATEC Web of Conf, 230, 02027.

16. Romashko, V. M., Romashko, O. V. (2018). Calculation of crack resistance of reinforced concrete elements taking into account the levels of formation of normal cracks. Coll. scientific works of UDUZT, 181, 58-65.

17. Romashko, O. V. and Romashko, V. M. (2019). Model of multilevel formation of normal cracks in reinforced concrete elements and structures. IOP Conf. Ser.: Materials Science and Engineering, 708(1), 012069.

18. Romashko, V. and Romashko, O. (2017). The construction peculiarities of the deformation and power model of concrete and reinforced concrete resistance. MATEC Web of Conf, 116 , 02028.

19. Romashko, V. M. (2016). Deformation-force model of resistance of concrete and reinforced concrete: monograph. Rivne: O. Zen.

20. DSTU B B.2.6-156: 2010. (2011). Constructions of buildings and structures. Concrete and reinforced concrete structures made of heavy concrete. Design rules. Kyiv: Ministry of Regional Development of Ukraine.

21. EN 1992-1-1. (2004). Eurocode 2: Design of Concrete Structures. Part 1-1: General Rules and Rules for Buildings. Brussels: CEN.

22. SP 63.13330.2012. (2013). Concrete and reinforced concrete structures. Basic provisions. Updated edition of SNiP 52-01-2003. Moscow: Ministry of Regional Development of Russia.

Рецензент: д-р техн. наук, проф. В.С. Шмуклер, Харківський національний університет міського господарства імені О.М. Бекетова, Харків, Україна
Автор: РОМАШКО-МАЙСТРУК Олена Василівна стариий викладач кафедри основ архітектурного проектування, конструювання та графіки
Національний університет водного господарства та природокористування
E-mail-romashkoolena@gmail.com
ID ORCID: http://orcid.org/0000-0003-3353-2268

\section{THE STUDY OF LEVEL FORMATION AND DISCLOSURE OF NORMAL CRACKS IN REINFORCED CONCRETE ELEMENTS}

O. Romashko-Maistruk

National University of Water Management and Nature Recourses Use, Rivne, Ukraine

This article is devoted to the study of the main patterns of normal cracks multilevel formation in reinforced concrete elements and structures. A critical analysis of the latest publications related to the theme of these studies is carried out. The classification is carried out and the main shortcomings of the known works on the four identified areas of research are identified. The most important elements of the method of reinforced concrete beams experimental research are developed and briefly described. The main characteristics of the prototypes, the conditions for their manufacture and storage are given. The most important results of testing reinforced concrete beams, concerning the main parameters and characteristics of level formation and crack disclosure are highlighted. It was confirmed that the process of normal cracks formation is indeed multilevel and is accompanied by a gradual disruption of the bond between reinforcement and concrete. According to the results of experimental studies, it has been established that in the real design of bending reinforced concrete elements, when calculating their crack resistance, it is possible to restrict oneself to only 2 levels of normal cracking.

The calculation of the step and normal cracks opening width in beams research was carried out according to the real multilevel and traditional "one-level" schemes of their formation. These calculations were carried out according to the author's general and simplified methods, according to a method that uses a linear function of the average adhesion stresses of reinforcement with concrete, according to the methods of current domestic and European standards and building rules. Their statistical comparison with the experimental studies results confirmed the effectiveness of those calculation methods in which the crack formation step is directly related to the basic laws and parameters of reinforcement to concrete adhesion. The results of this comparison showed that the author's general method, based on the use of a nonlinear function of the reinforcement with concrete average adhesion stresses, turned out to be the most accurate.

Keywords: reinforced concrete, elements, adhesion, reinforcement, cracks, levels of formation, step, width. 